\title{
Review on News About Midwifery and Fertility Covered on Newspapers in Turkey
}

\section{Türkiye'deki Gazetelerde Yer Alan Ebelik Ve Doğurganlığa İlişkin Haberlerin İncelenmesi}

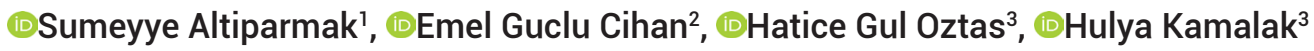 \\ 'Inönü University, Faculty of Health Sciences, Department of Midwifery, Malatya, Turkey \\ ${ }^{2}$ Ekinözü State Hospital, T.C. Ministry of Health, Kahramanmaraş, Turkey \\ ${ }^{3}$ Sütçü İmam University, Faculty of Health Sciences, Department of Midwifery, Kahramanmaraş, Turkey \\ Copyright@Author(s) - Available online at www.dergipark.org.tr/tr/pub/medr \\ Content of this journal is licensed under a Creative Commons Attribution-NonCommercial 4.0 International License cc)
}

\begin{abstract}
Aim: This research was conducted with the purpose of making content analysis of the news about midwifery and fertility covered on newspapers in Turkey.

Material and Method: Population of this retrospective descriptive study consisted of news of nine newspapers with the highest circulation in Turkey which were accessible on the internet.The data was obtained from the newspaper news that were included in the scope of the research as a result of review using the determined keywords (mother, breast milk, baby, birth, midwife, midwifery, breastfeeding, pregnant, gestation, pregnancy, postpartum, newborn). The data obtained was recorded on the 'News Evaluation Form' by the researchers.Percentage distribution, arithmetic average and standard deviation were used in the statistical evaluation.

Results:Highest percentage of reviewed news were obtained from Newspaper 4 by $27.8 \%$, Newspaper 6 by $24.7 \%$ and Newspaper 1 by $11.1 \%$ respectively. It was determined that $9.5 \%$ of the news were in the headline, $1.6 \%$ were in subheading, $72.5 \%$ had appropriate picture and $67.1 \%$ were of newsworthy.It was determined that only $28.5 \%$ of the news were written by healthcare professionals, $55.4 \%$ covered special days for midwives and $63.9 \%$ did not include the source of the article.It was determined that titles of $49.4 \%$ of the news were perceived as positive impact and $33.9 \%$ contained titles in relation to pregnant-pregnancy words. It was determined that physical status and/or problem (22.5\%) matters were discussed most frequently in the contents of newspaper news.

Conclusion:It was determined that the news obtained were intended for giving updated status, of informative news quality in general and a very few of them were discussed by healthcare professionals. In addition, it was determined that more than half of the newspapers covered news of special days for midwives,only one third of the news contained the source for the article, approximately half of them were positive news and news regarding pregnant-pregnancy keywords were written most frequently.
\end{abstract}

Keywords:Mother, fertility, midwife, newspaper, woman.

Öz

Amaç: Bu araştırma, Türkiye'deki gazetelerde yer alan ebelik ve doğurganlık ile ilgili haberlerin içerik analizini yapmak amacıyla gerçekleştirildi.

Materyal ve Metot Retrospektif tanımlayıcı türde olan bu araştırmanın evrenini Türkiye'de en yüksek tiraja sahip dokuz gazetenin internet ortamında ulaşılabilen haberleri oluşturdu. Veriler, araştırma kapsamına alınan gazete haberlerinden, belirlenen anahtar kelimeler (anne, anne sütü, bebek, doğum, ebe, ebelik, emzirme, gebe, gebelik, hamilelik, lohusa, yenidoğan) ile yapılan tarama sonucunda elde edildi Elde edilen veriler araştırmacılar tarafından 'Haber Değerlendirme Formu'na kaydedildi. İstatistiksel değerlendirmede; yüzdelik dağılım, aritmetik ortalama ve standart sapma kullanıldı.

Bulgular. İncelenen haberler sırasıyla en fazla \% 27.8 ile Gazete 4, \%24.7 ile Gazete 6, \%11.1 ile Gazete 1'den elde edilmiştir. Haberlerin; \%9.5'inin manşet, \%1.6'inin sürmanşette yer aldığı, \%72.5'inde konuya uygun görselin olduğu, \%67.1'inin ise aktüel haber niteliği taşıdığı belirlendi. Haberlerin sadece \%28.5'inin sağlık çalışanları tarafından yazıldığı, \%55.4'ünde ebelere ait özel günlerin konu edildiği ve \%63.9'unun yazı içeriğine ilişkin kaynağının belirtilmediği saptandı. Haberlerin; \%49.4'ünün başlığının olumlu etki olarak algılandığı ve \%33.9'unun gebe-gebelik-hamile-hamilelik kelimelerine ilişkin başlık içerdiği saptandı. Gazetelerdeki haber içeriklerinde en sık fıziksel durum ve/veya problem (\%22.5) konularının ele alındığı belirlendi.

Sonuç: Elde edilen haberlerin genellikle güncel durum vermeye yönelik, bilgilendirici haber niteliğinde olduğu ve çok az bir kısmının sağlık çalışanları tarafından ele alındığı belirlenmiştir. Ayrıca gazetelerin yarıdan fazlasında ebelere ait özel günlere ilişkin haberlerin yer aldığı, haberlerin sadece üçte birinin yazı içeriğine ilişkin kaynağının belirtildiği, yaklaşık yarısının olumlu haber niteliğinde olduğu ve en sık gebe-gebelik-hamile-hamilelik anahtar kelimelerine ilişkin haberlerin kaleme alındığı belirlenmiştir.

Anahtar Kelimeler. Anne; doğurganlık; ebe; gazete; kadın

Geliş Tarihi / Received: 21.01.2021 Kabul Tarihi / Accepted: 17.02.2021

Sorumlu Yazar /Corresponding Author. Sumeyye Altiparmak, Inonu University, Faculty of Health

Sciences, Department of Midwifery, Malatya, Turkey. E-mail: sumeyye.kandemir@inonu.edu.tr 


\section{INTRODUCTION}

Communication is a significant method of transferring knowledge and experience and with communication, consensus and awareness are formed about a topic in the society. Communication about disease and health constitutes the most vital aspect of human experiences (1). One of the fundamental objectives of communication in health is to spread knowledge and educate people about health and diseases (2). Health communication by means of various media tools such as television, printed and visual media and internet has increased gradually in the recent years (3). Newspapers play a significant role in health communication. Newspapers allow people to access to information including symptoms of the disease, risk factors, existing treatments and recommendations for health-improving behaviours (2). For that reason, it can be said that healthcare information offered by printed and visual media has more physical impact and reach than the information offered by healthcare professionals (4).

Newspapers are considered as one of printed media tools with the potential to change society's health status positively or negatively (5). The health of women, who have a significant place in the society, are under such positive and negative impact of the newspaper (6). Women's health is affected by a number of factors such as psychosocial factors, family and social structure, woman's individual health status, fertility behaviour and quality of healthcare services. One of the most important ones of those factors is considered to be the media (5). Key role for protecting and improving women's health is given to midwives (6). Midwives offer services during pregnancy, birth and the entire postpartum period in which the woman is located in the centre (7). In that context, midwives offer care and service to the woman and the newborn fundamentally and to the society generally (8). Midwifery has a significant social position and midwifery has a direct impact on public health (9).

A lot of positive and negative news about midwives and fertility were covered in the media. It is necessary that the impact of media especially on people's perceptions and expectations about birth is examined carefully (10). In the literature, it is reported that pregnancy and labour is not a disease, but a natural, normal and healthy function of the body and all kinds of unnecessary intervention have negative impacts on the birth process. However, painful labour scenes shown on visual media cause that women create a negative labour image (11). Therefore, the image that labour is a painful, bloody and scary occasion makes the women think that they will have this terrifying experience about vaginal labour during pregnancy as well and this focuses their preferences on C-section (5). This may increase unnecessary $\mathrm{C}$-section rates. It was presented in studies conducted that mothers obtain most of the information about pregnancy, labour and child raising from printed media and printed media is effective in medicalizing the labour (12).

World Health Organization (WHO) states that women want a positive labour experience which meets their personal and sociocultural expectations (13). Therefore, it is necessary to use media's support as well for positive labour experience and continuous midwife support. Reducing $\mathrm{C}$-section rates and encouraging the society towards vaginal delivery is quite important for both women's health and national aspects. For that reason, it is necessary to expand midwifery roles which have narrowed down in our country's healthcare system the media is largely responsible in that matter. Health news without due diligence damage the public health (14). It is necessary to encourage proper use of the media which might be quite effective in improving women's health (5). The aim of this research is to make content analysis for the news about midwifery and fertility written by nine national newspapers with high circulation in Turkey and shed light to the press perception in Turkey about these matters.

\section{MATERIAL AND METHODS}

Population of this retrospective descriptive study consisted of news of nine newspapers with the highest circulation in Turkey between 04.05.2020 and 10.05.2020 which were accessible on the internet between 1 July 2019 and 1 July 2020. In daily circulation assessment, the data on May 2020 periodical of Press Advertisement Agency was taken into consideration (15). According to the data taken into consideration; Sabah, Hürriyet, Sözcü, Milliyet, Türkiye, Posta, Akşam, Yeni Şafak and Takvim newspapers were reviewed within the scope of the study using Google search engine. In the evaluation, newspapers are indicated as Newspaper 1 (Sabah), Newspaper 2 (Hürriyet), Newspaper 3 (Sözcü), Newspaper 4 (Milliyet), Newspaper 5 (Türkiye), Newspaper 6 (Posta), Newspaper 7 (Akşam), Newspaper 8 (Yeni Şafak) and Newspaper 9 (Takvim). Headline news of the nine newspapers identified according to circulation, which were accessed on the internet within the last one year and news obtained as a result of searching the keywords "mother, breast milk, baby, birth, midwife, midwifery, breastfeeding, pregnant, gestation, pregnancy, postpartum, newborn" in the search engines on websites of the newspapers were evaluated (16). 345 news were reached about midwifery and fertility. However, 29 duplicate news were eliminated and 316 news in total constituted the population of the research.

The news obtained as a result of review were read by the primary researcher who is a midwifery specialist and the links on the internet address bar and the contents of the news suitable for inclusion criteria were recorded. A similar procedure was implemented by the three other researchers and deficient selection was avoided and suggested news were included in the data collection form. Inclusion criteria was that the headline or contents of the news contain at least a few sentences about midwifery and fertility.

The data was collected by means of the data collection form drawn up by the researchers. News were reviewed from official webpages of the newspapers. Online newspaper news link and news content were written in a Word document and the data obtained was entered in the 
form. Each researcher evaluated the news and necessary corrections were made on the data collection form and the study is completed. The definitions used in evaluation of the research data are:

News: "Information, advice obtained about an incident, a phenomenon. Information conveyed through communication or media organs" (17).

Mother: Woman with child, mom, old lady (18)

Breast milk: Breast milk is the milk produced by the female human and used for feeding the newborn (19).

Baby: Breastfeeding or lap child (18).

Birth: The act of being born (18).

Midwife: The woman who helps women when they are having a baby (18).

Midwifery: "The state of being a midwife or the work done by midwife. The gift given to the midwife who helped the labour (18).

Breastfeeding: The process of feeding a mammal's breast milk to her infant (20).

Impregnate: With a baby in her womb (woman or animal), loaded, pregnant (18).

Pregnancy: The state of being pregnant, gestation (18).

Pregnant: Impregnate (18).

Gestation: Pregnancy (18).

Postpartum: A woman who had a baby recently (18).

Newborn: 0-28 days old baby (18).

Newspaper: "A periodical publication published daily or on certain intervals with or without commentary to deliver news and information about politics, economy, culture and other topics" (18).

Circulation: Number of printing (18).

\section{Data Collection Tools News Evaluation Form}

It is a form which is prepared by the researchers in accordance with literature review and contains questions about reviewing the news (21-24).

Questions used for reviewing the news are the name of the newspaper, location of the news on the main page (subheading, headline, etc.), type of article (updated status/information, column, interview, etc.), visuals of the news (photograph-picture-graph available or not, etc.), impact type of the news, source of the news, owner of the news, news content (diagnosis, treatment, physical problems, etc.), presence of news on midwives' day, midwives' week, etc. on the newspaper, the period when the news is published (weekdays, weekend), status of citing the source for article content, positive or negative impact of the news title, headline, keyword searched according to headline, the link to the news.

\section{Data Evaluation}

The data is encoded and evaluated on computer using SPSS 25.0 software package (Statistical Package for the Social Sciences Inc., Chicago, IL, USA). Percentage distribution, arithmetic average and standard deviation are used in statistical evaluation.

\section{Ethical Regulations}

For implementation of the research, approval is taken from Republic of Turkey, İnönü İnonu University, Scientific Research and Publication Ethical Committee, Medical Sciences Non-Invasive Clinical Researches Ethical Committee (Decision No: 2020/937).

\section{Limitations of the Research}

This research is limited to the news published on 9 newspapers between 1 July 2019 and 1 July 2020 . Another limitation is that the news were reviewed on the web pages of the newspapers, not on the printed original copies.

\section{RESULTS}

Distribution of the number of news covered in newspapers is given in Table 1. According to the results obtained, the highest percentage of reviewed news were obtained from Newspaper 4 by $27.8 \%$, Newspaper 6 by $24.7 \%$ and Newspaper 1 by $11.1 \%$ respectively.

Table 1. Distribution of the number of news covered in newspapers $(n=316)$

$\begin{array}{lcc}\text { Newspapers Name } & \mathbf{n} & \% \\ \text { Newspaper 1 (Sabah) } & 35 & 11.1 \\ \text { Newspaper 2 (Hürriyet) } & 34 & 10.8 \\ \text { Newspaper 3 (Sözcii) } & 20 & 6.3 \\ \text { Newspaper 4 (Milliyet) } & 88 & 27.8 \\ \text { Newspaper 5 (Türkiye) } & 28 & 8.9 \\ \text { Newspaper 6 (Posta) } & 78 & 24.7 \\ \text { Newspaper 7 (Akşam) } & 18 & 5.7 \\ \text { Newspaper 8 (Yeni Şafak) } & 8 & 2.5 \\ \text { Newspaper 9 (Takvim) } & 7 & 2.2 \\ \text { Total } & 316 & 100\end{array}$

Distribution of keywords included in headlines is given in Table 2. When we look at the keywords included in headlines, there are news about pregnant-pregnancy by $33.9 \%$, birth by $16.8 \%$ and breast milk-breastfeeding by $15.2 \%$.

$\begin{array}{lcc}\text { Table 2. Distribution of keywords included in headlines }(\mathbf{n = 3 1 6 )} \\ \text { Keywords Included in Headlines } & \mathbf{n} & \% \\ \text { Pregnancy -Pregnant-Pregnant Women } & 107 & 33.9 \\ \text { Birth } & 53 & 16.8 \\ \text { Breast Milk-Breastfeeding } & 48 & 15.1 \\ \text { Baby-Newborn } & 46 & 14.6 \\ \text { Mother } & 30 & 9.5 \\ \text { Postpartum woman-Postpartum } & 21 & 6.6 \\ \text { Midwife-Midwifery } & 11 & 3.5 \\ \text { Total } & 316 & 100.0\end{array}$


Table 3. Distribution of descriptive features about newspaper news $(n=316)$

\section{Descriptive Features \\ News Position on Home Page}

Other Part / Section (Upper, Middle and Lower Part)

Headline

Subheading

News Post Type

Current News

Interview

Corner post

Magazine

Public (T. C. Ministry of Health and / or Appointment)

Advertisement

Visual Status of the News

There are visuals and suitable for the topic

There are visuals and not suitable for the topic

No visuals

The Impact of the Headline

Positive $^{\mathrm{a}}$

Neither positive nor negative / Information

Negative $^{b}$

News Source

Citizens of the Republic of Turkey

External sources

Foreign Nationals Living in Turkey

\section{News Owner}

Newspaper worker / writer

Expert / Health worker

News Content

Physical matters and/or problems (Pregnancy and breastfeeding pe-riod changes, etc.)

Description/introduction (Introduction of a product used in breastfee-ding period etc.)

Diagnosis-treatment ("What is Mastitis and how it should be treated" etc.)

Pregnancy and Breastfeeding during Covid-19

Psychosocial matters and/or problems (Postpartum depression and treatment etc.)

Legal matters and/or problems ("Sued the Doctor" etc.)

News about healthcare professionals

Magazine (Pregnancy and birth news of celebrities etc.)

Economic matters and/or problems (Child support after birth etc.)

News about healthcare organizations

Aesthetic matters and/or problems (Vaginoplasty etc.)

The Period When the News was Published

Weekdays

Weekend

Source of Text Content

There is a source

News Status Regarding Special Days Regarding Midwives

Yes

No

Total
175

55.4

a Sample Headline; "At least 7.470 Turkish Liras for new mothers in 2020 (https://www.posta.com.tr/)" etc.

${ }^{b}$ Sample Headline; "Breaking News: Terrible end in the birth in Ankara! Baby's head off... (https://www.milliyet.com.tr/)", "Breaking News: Terrifying birth moments astounded those around! Twisted in pain... (https://www.sabah.com.tr/)" etc. 
Distribution of descriptive features about newspaper news is given in Table 3 . The news found are on the headline by $9.5 \%$ and subheading by $1.6 \% .72 .5 \%$ of the news had visuals suitable to the topic. The impact that the news left is evaluated as positive by $49.4 \%$. The sources of the news written by newspaper employees by $71.5 \%$ are the citizens of the Republic of Turkey by $94.6 \%$. When we look at the news covered on newspapers, the most frequent news content is identified as physical status and/or problem by $22.5 \%$. $55.4 \%$ of the newspapers covered news about special days for midwives. $82.3 \%$ of the news were published on weekdays. It was found that $63.9 \%$ of the news did not cite the source for the article content.

\section{DISCUSSION}

Today, when we say media (mass communication tools); especially newspaper, magazine, theatre, video, cinema, radio, television and internet come to mind (25). Media is considered as a significant force in all fields. One of these fields is the field of health (24). The power of media in the field of health has a significant impact of public's perceptions of health problems (26). Media is used especially in critical areas such as preventing and management of addictive items such as smoking-alcohol or cancer and chronic diseases. Furthermore, using media as a source of information in the field of health takes a significant place in acquiring and maintaining health improving behaviours (27). Media has important impacts on women's and family health. It is especially emphasized that defective and deficient information on labour or terrifying scenes and dialogues covered on the media create a negative impact on vaginal delivery and has a great share in the increase in elective $\mathrm{C}$-section rates $(5,24,28,29)$. In this section, results on the news of nine national newspapers with high circulation in Turkey about midwifery and fertility are discussed with the related literature.

In this research in which we review the newspaper news on midwifery and fertility concepts in Turkey; the most news were obtained from Newspaper 4 by $27.8 \%$, Newspaper 6 by $24.7 \%$ and Newspaper 1 by $11.1 \%$ (Table $1)$. In the research, it was found that the position of news on midwifery and fertility is mostly on the other part (top, middle and bottom part) $(88.9 \%)$ (Table 3$)$. In literature review, it was found in a study reviewing news on women that the news are quite few on the headline and subheading $(21-23,30)$ and health related news are mostly published on other parts of the newspaper (22) similar to our results.

In the research, type of the news on midwifery and fertility concepts consists of actual news by $67.1 \%$. In terms of impact type of the news, it was determined that $72.5 \%$ of the news are informative news (Table 3 ). As specified in the report drawn up by United Nations Educational, Scientific and Cultural Organization (31) commission, the functions of the media are listed as informing, socialization, motivation, discussion, education, cultural development, entertainment and participation (22-25,
$30,31)$. In addition, there is a society trying to increase their e-health literacy for keeping healthy and it is usual that such news are made $(23,32)$. When evaluated in that respect, the fact that news on midwifery and fertility obtained on the research are informative is a result in compliance with the literature $(24,25,32)$. However, it is also important that the information given contains correct information on the matter and is supported by the experts or organizations $(23,33)$. In this research, it was determined that $71.5 \%$ of the news are made by newspaper employees and only $28.5 \%$ are made by healthcare professionals (Table 3 ). In literature review, it is thought that health news reviewed are mostly made by newspaper reporters due to the reasons that there is no standard about the source of newspaper news in Turkey as well as the entire world and the news are made mostly with rating concerns $(24,33)$. Furthermore, it is a known fact that newspapers have the potential to change attitude, behaviour and perceptions of masses as means for conveying information. For that reason, scope and content of every news on health and by whom the content is prepared become important (24). For a "healthy" health journalism away from sensation, it is necessary to employ health reporters specialized on their fields at all media organizations (23). In addition, it was determined that $55.4 \%$ of the news obtained in this research covered news on special days for midwives (Table 3 ). As many professional groups, coverage of news on midwives' day or midwives' week on newspapers can also be evaluated as a positive result. The result obtained can be interpreted as a positive indicator showing that news on special days for midwives are covered on newspapers with high circulation in Turkey.

In the research, it was found that the news on midwifery and fertility contained visuals and such visuals are suitable for the matter (72.5\%) (Table 3 ). In addition, it was determined that a great part of the news sources is the citizens of the Republic of Turkey (94.6\%) (Table 3). As a result of the investigation made, it can be said that this result complies with the literature (22). Unlike our result, studies reporting that news about external sources are made more were found as well $(30,33)$. When the news contents are reviewed, it is seen that there are news on physical matters and/or problems such as "pregnancy and breastfeeding period changes" (22.5\%), description/ introduction such as "introduction of a product used in breastfeeding period etc." (22.2\%), diagnosis-treatment such as "What is Mastitis and how it should be treated" $(15.5 \%$ and "pregnancy and breastfeeding during Covid-19" (11.1\%) (Table 3). When the studies in the literature are reviewed, it was seen that other studies containing keywords focus on physical matters and/ or problems such as changes concerning women and experience when a woman becomes a mother similar to our result $(22-24,34)$. Furthermore, it is necessary not to lead the individual and society to panic or to avoid news which would give false hope as much as possible. For that reason, it is important to be diligent while choosing 
the words to be used in health news $(21,23,33)$. In the review, it was determined that news evaluated in this research have left a positive impact on $49.4 \%$ of the readers. In literature review, it was found that there is mostly a male-dominant discourse in the news on and about women, but the news in which women are reflected positively are in majority (35).

When we look at the searched keyword according to the headline in the results of our study, it was determined that there are news on pregnant-pregnancy by $33.9 \%$ and on breast milk and breastfeeding by $15.2 \%$ (Table 2 ). In literature review, it was found that keywords similar to our result are used in the studies on the news about women and women's health $(35,36)$. It can be said that this is because news on women's fertility are news that can draw attention of all walks of life (22). Furthermore, it was found that sources for the article contents are not cited in $63.9 \%$ of the news obtained (Table 3 ). When we look at the health news on newspapers, it is seen that the source of the article contents is not cited in most of them (Table 3). Although news in which sources are cited in were found in literature review (22), there are also studies in which the sources are cited at very low rates similar to our result (33). While press groups do not give much importance to the source, the reader is curious about and wants to learn the source. The reader would like to be sure about the accuracy of the information given by looking at the news source. In addition, technological developments are at top level today and there are more opportunities to reach the sources in news made by journalists on the field of health. In that respect, it is recommended that right sources are accessed in the news and such sources are cited in the news $(23,33)$.

\section{CONCLUSION}

In this research where content analysis is made for the news on midwifery and fertility covered in nine national newspapers with high circulation in Turkey; it was determined that the news are intended for giving updated status, they are newsworthy and very few of the news are written by healthcare professionals. In addition, it was determined that more than half of the newspapers covered news of special days for midwives, only one third of the news contained the source for the article, approximately half of them were positive news and news regarding pregnant-pregnancy keywords were written most frequently in terms of the keywords searched according to the headlines.

In the society, women use the mass communication tools at the most and they make searches with the purpose of obtaining information for themselves and their families. Midwives who are advocate and protector of women's rights should have a raised awareness about the news on women's health covered in the media and they should raise awareness among women about these matters. Midwives should use the enlightening and guiding power of mass communication tools such as newspapers and television effectively and productively in matters related to their field. Furthermore, it should be ensured that media, which might be effective in improving women's health and supporting fertility, is used properly. Important duties rest on both healthcare and media professionals on that matter.

\section{Acknowledgment}

We would like to thank the Press Advertisement Institution for sharing the daily circulation evaluation of the newspapers and Gazeteoku Publishing (https:// www.gazeteoku.com/) for providing online access to newspaper news.

Financial disclosures: All authors report no financial interests or potential conflicts of interest.

Conflict of Interest: The authors declare that they have no competing interest.

Ethical approval: Prior to the study ethical approval was obtained from the Scientific Research and Publication Ethics Committee of the Malatya Inonu University of Health Sciences in Turkey on (Decision No: 2020/937).

\section{REFERENCES}

1. Koçak A, Bulduklu Y. Health Communication: Motivations of elderly people to watch health programs broadcasted on television. selcuk university faculty of communication. Academic J. 2010;6:5-17.

2. Rimal RN, Lapinski MK. Why health communication is important in public health. Bull World Health Organ. 2009;87:247-7.

3. Redmond N, Baer HJ, Clark CR, et. al. Sources of health information related to preventive health behaviors in a national study. Am J Preventive Med 2010;38:620-7

4. Song $\mathrm{H}$, Omori $\mathrm{K}, \mathrm{Kim} \mathrm{J}$, et. al. Trusting social media as a source of health information: Online surveys comparing the United States, Korea, and Hong Kong. J Med Int Res 2016;18-25.

5. Özbaş S, Özkan S. The use and effect of media in improving women's health. TAF Preventive Medicine Bulletin 2010;9 541-6.

6. Aktaş S. Effects of media on women's aesthetics and role of midwife, Anadolu J Nursing Health Sci 2014;17:3

7. Dahlberg U, Aune I. The woman's birth experience. The effect of interpersonal relationships and continuity of care. Midwifery 2013;29.407-15

8. Tezbaşaran IY. Legal responsibilities of midwives. Medical academy. 2016. Access: https://www.medikalakademi. com.tr/ebelerin-yasal-sorumluluklari/Dateof access date 01.07 .2018

9. Yörük S. Development of Education Program for Primary Care Practice Skills of Balıkesir University Health School Midwifery Department 4th Grade Students, Dokuz Eylül University Health Sciences Institute, (Unpublished Doctorate Thesis), İzmir, 2011 , p. 9.

10. Bick D. Media portrayal of birth and the consequences of misinformation. Midwifery 2010;26:147-8. 
11. Hundley V, Luce A, van Teijlingen E. Do midwives need to be more media savvy? MIDIRS Midwifery Digest. 2015;25:510.

12. McIntyre MJ, Francis K, Chapman Y. Shaping public opinion on the issue of childbirth; a critical analysis of articles published in an Australian newspaper. BMC Pregnancy Childbirth 2011;11:47.

13. WHO recommendations: intrapartum care for a positive childbirth experience. Geneva: World Health Organization; 2018. Licence: CC BY-NC-SA 3.0 IGO.

14. Kızılca Çakaloz D. and Çoban A. The Role of Midwife in Reducing Cesarean Deliveries, Arch Source Rev J. 2019;28:51-59.

15. https://bik.gov.tr/kurumsal/genel-mudurluk/genel-mudur/ access date 15.05.2020

16. https://www.gazeteoku.com/ access date 15.05.2020

17. http://www.tdk.gov.tr/ access date 15.05.2020

18. https://sozluk.gov.tr/ access date 15.05.2020

19. https://tr.wikipedia.org/wiki/Anne_s\%C3\%BCt\%C3\%BC / access date 16.05.2020

20. https://tr.wikipedia.org/wiki/Emzirme/ access date 16.05.2020

21. Demiray A. Representation of Violence Against Women in Newspaper News and Patriarchal Ideology (Sample of Cumhuriyet, Zaman, Hürriyet, Posta Newspapers) Mersin University Institute of Social Sciences, Department of Women's Studies. 2014, p. 14-7.

22. Damlapinar Z, Işik U. Health Content Press News and Approach to Children: A Content Analysis. Gümüşhane University Communication Faculty Electronic Journal. $2017 ; 5,1$.

23. Utma S. Reading Health News in the Media Correctly. Adnan Menderes University Atça Vocational School. Int J Social Sci 2017;57:597-605.

24. Çapar H, Çakmak C. Newspapers as a source of public health information: Analysis of health-related news. J Health Scholars 2019;6:18-26.

25. Türkoğlu N. From Communication Sciences to Cultural
Studies, Social Communication. Definitions, Concepts, Discussions. 1st Edition. Istanbul: Babylon Publications; 2004, p. 19- 127.

26. Karakuş E. Health News in Newspapers: Medicalization of Life, Individualization of Health and Woman in the Consumption Triangle. Dumlupınar University Institute of Social Sciences, Department of Sociology 2013, pp. 66-70.

27. Avcı K, Avşar Z. Health Communication and New Media. Communication Theory Res J 2014;39:181-90.

28. Aktaş S. Influences of media on women's aesthetics and the role of midwife. Anadolu J Nursing Health Sci 2014;17: 3

29. Yavuz A, Küngerü A. Woman As Other: The representation of woman in newspapers. Int $\mathrm{J}$ Academic Value Studies 2017;3:404-18.

30. Sutherland G, Easteal P, Holland $\mathrm{K}$, et al. Mediated representations of violence against women in the mainstream news in Australia. BMC Public Health 2019;19:502.

31. UNESCO (1977) Media Studies in Education. Printed in the workshops of the UNESCO, Paris. http://unesdoc.unesco. org/ımages/0002/000238/023803eo.pdf/ access date 04.01.2021.

32. Şengül $H$, Çınar $F$, Çapar $H$, et al. - Health literacy levels and attitudes towards internet use for faculty of health sciences students: an example of Vakıf University. J Social Humanities Sci Res (JSHSR) 2017;4:1277-87.

33. Kumbasar B. Health News in Newspapers Published in Istanbul. Master's thesis. Marmara University Institute of Social Sciences, Communication Sciences Department. 2006.p: 73

34. Erden G, Akdur S. Violence and murders of women in domestic violence against women in Turkey. J Clin Psychol 2018;2:128-39

35. Basmacı G. Women's Representation in Local Press. International Media Studies Congress. 20 to 23 April / April Antalya -Turkey. p: 623

36. Cho K, Kim S, Woo Y. Analysis of women's health online news articles using topic modeling. Osong Public Health Res Perspect 2019;10:158-69. 